\title{
Comparison between Amorphous and Tandem Silicon Solar Cells in Practical Use
}

\author{
Masato Ohmukai ${ }^{1}$, Akira Tsuyoshi ${ }^{2}$ \\ ${ }^{1}$ Department of Electrical Engineering, Akashi College of Technology, Akashi, Japan \\ ${ }^{2}$ Department of Electrical Engineering, Kobe City College of Technology, Kobe, Japan \\ Email: tsuyoshi@kobe-kosen.ac.jp
}

How to cite this paper: Ohmukai, M. and Tsuyoshi, A. (2017) Comparison between Amorphous and Tandem Silicon Solar Cells in Practical Use. Journal of Power and Energy Engineering, 5, 9-14. https://doi.org/10.4236/jpee.2017.54002

Received: March 28, 2017

Accepted: April 23, 2017

Published: April 26, 2017

Copyright (C) 2017 by authors and Scientific Research Publishing Inc. This work is licensed under the Creative Commons Attribution International License (CC BY 4.0).

http://creativecommons.org/licenses/by/4.0/

c) (7) Open Access

\begin{abstract}
Solar cells are now widely used as a clean method for electric energy generation. Among various type of solar cells, we compared the ability between amorphous and tandem (amorphous and polycrystalline) silicon solar cells by means of simultaneous running test. This kind of comparison is of importance practically, because the comparison of only inherent characteristics cannot include environmental parameters such as temperature totally. It was concluded that both types of solar cells provided almost the same energy for one year. The amorphous silicon solar cell provided more energy in summer while the tandem solar cell was advantageous in winter. It is due to the fact that the decrease in energy conversion at the higher cell temperature is more noticeable in tandem solar cells.
\end{abstract}

\section{Keywords}

Solar Cell, Amorphous Silicon, Tandem Type Solar Cell, Monthly Generation Energy, Panel Temperature

\section{Introduction}

Solar cells are quite attractive to generate electricity without any environmental disturbance such as thermal or atomic power generation of electricity [1] [2]. The thermal power generation releases carbon dioxide during the burning of petroleum, which has been recognized as a global warming problem. The main disadvantage of solar cells is the high initial cost. But the cost will be lowered as the solar cells become popular.

There are several kinds of materials for the solar cell nowadays [3] [4] [5]. The most important and widely used solar cells are made from silicon. In the silicon-based solar cells, there are three types of solar cells: polycrystalline, amorphous and tandem solar cells. The tandem-type solar cells consist of more hetero 
layers stacked continuously for an improvement. Amorphous silicon is more attractive than crystalline silicon owing to its broader band gap $(1.7 \mathrm{eV})$ where crystalline silicon has a $1.1 \mathrm{eV}$ band gap, corresponding to the abundant light of sun shine and also easy way of fabrication process. On the other hand, the tandem solar cells consist of two layers of amorphous silicon and polycrystalline silicon for the purpose of the absorption of light in the wider spectral range than that with one kind. There is another type of a tandem solar cell that consists of an amorphous silicon layer and a micro-crystalline silicon layer [6]. Anyway, the sophisticated structure is surely more efficient in the energy conversion from the viewpoint of device performances [6].

Since solar cells are actually used in a rigorous environment, the comparison of the characteristics in a condition-controlled laboratory makes little sense to discuss which is superior for the practical use. Then we tried the running test through one year on the two kinds of silicon-based solar cells: amorphous and tandem solar cells. In Japan there exist four seasons and temperature varies approximately from 0 up to $35^{\circ} \mathrm{C}$ during a year. We then discuss the difference of properties of the two kinds of solar cells from the viewpoint of practical use.

\section{Experimental}

Both two types of solar cells, made by Kaneka co. Ltd., were installed on the top of four-story building (the latitude: $34^{\circ} 41^{\prime}$ ) with an angle of elevation of $5^{\circ}$. Since the elevation angle is far smaller than the latitude, the installation cost can be reduced formidably. The schematic diagrams of the two types of solar cells are depicted in Figure 1. The rated maximum output power was $4.5 \mathrm{~kW}$ for the both. The nominal values of the energy payback time [7] [8], maximum output power density and electric generation efficiency were 1.6 years, $70 \mathrm{~W} / \mathrm{m}^{2}$ and $7 \%$ for the amorphous solar cell, and 1 year, $88 \mathrm{~W} / \mathrm{m}^{2}$ and $8.8 \%$ for the tandem solar cell, respectively. The appearances of the two kinds of solar cells are different. The amorphous type has reddish brown color while the tandem type has black color.

The experiment was performed through a year to obtain the total generated

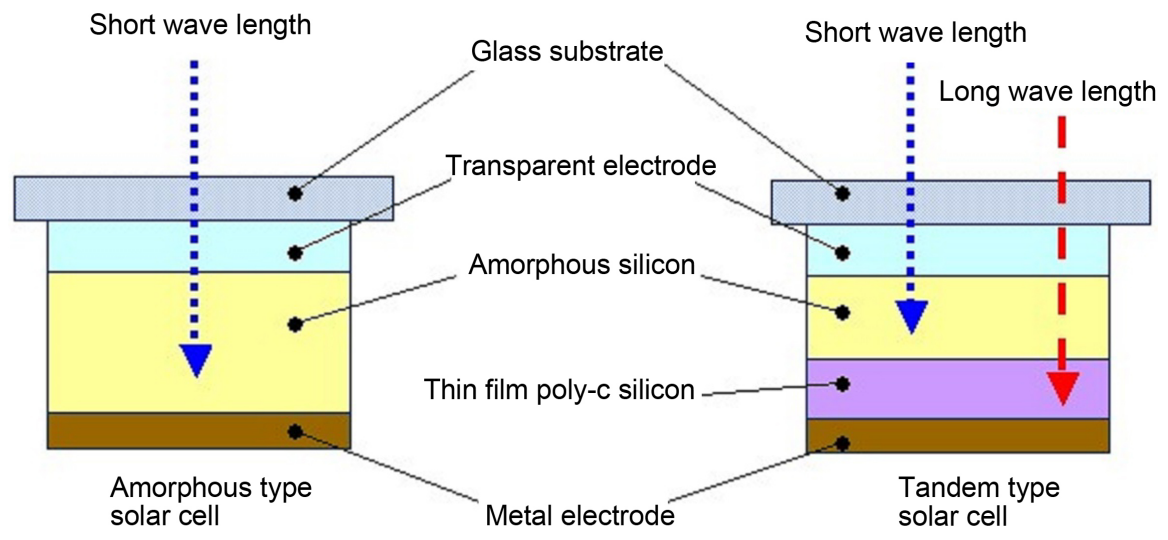

Figure 1. The schematic diagram of the two types of solar cells: Amorphous silicon (left) and tandem (right) solar cells. 
electric generation during a month. For the environmental conditions, the ambient temperature, the solar panel temperatures, and the output power were monitored for the two kinds of solar cells with a thermocouple, and a power high tester (Hioki 3169), respectively. The generation energy was obtained by the integration of the output power by a computer.

\section{Results and Discussion}

The three temperatures (ambient, the two kinds of solar panels) and the output power of the panels are shown in Figure 2 and Figure 3 for a sunny day in May and a rainy day in June, respectively. In the 365 data, the typical set of data for sunny and rainy days are given here. The ambient temperature was fit in the

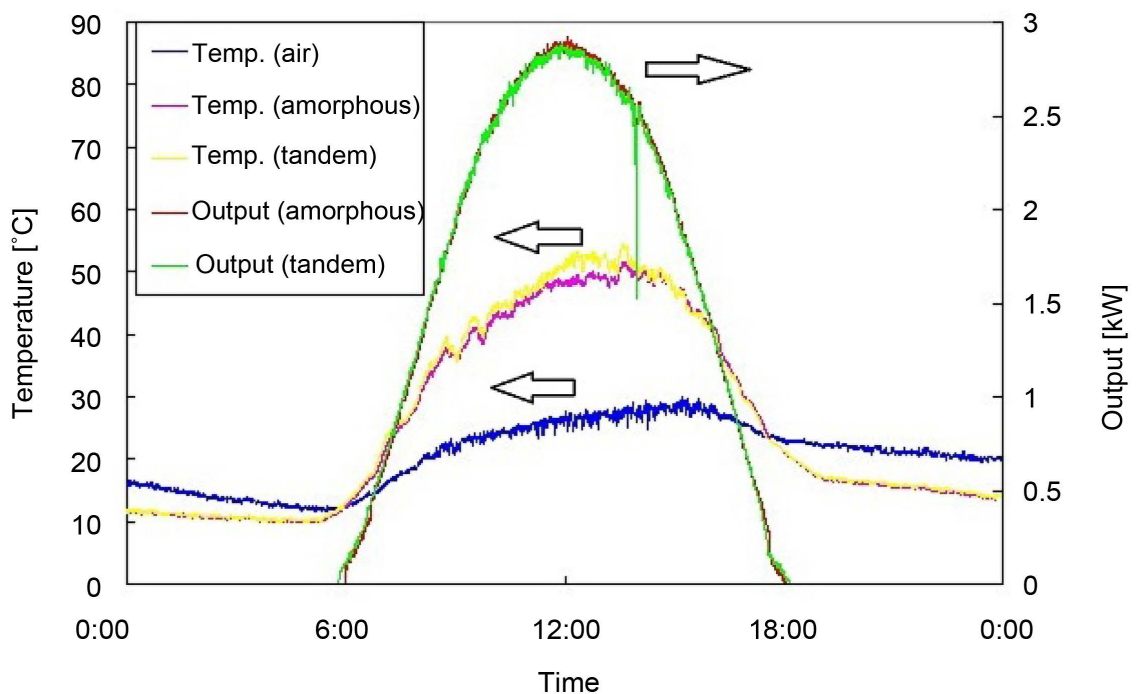

Figure 2. The one-day temperature variation of ambient air and the two solar cells. The output power variation for each cell is also shown. This is the data on a sunny day.

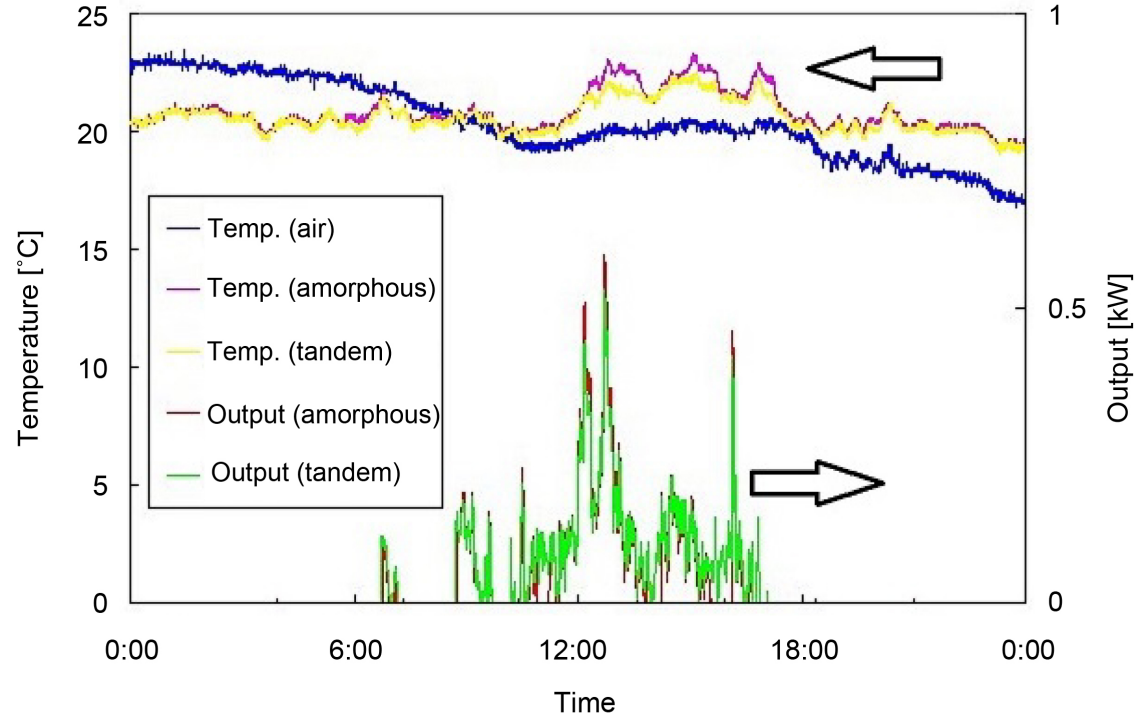

Figure 3. The one-day temperature variation of ambient air and the two solar cells. The output power variation for each cell is also shown. This is the data on a rainy day. 
range between 10 and 30 degree Celsius. The day-to-night difference is larger in a sunny day as is clear by comparing the two figures. The panel temperature, on the other hand, was not so different from the ambient temperature in a rainy day. But it was raised up to 50 degree Celsius in a sunny day.

We next consider the output power in both days. For the sunny day output power rises just under $3 \mathrm{~kW}$ at noon. Though the panel temperature reaches its maximum around 15 o'clock in the afternoon, the output power is directly related to the intensity of sunlight. In a rainy day, the output power is far less than that in the sunny day, but no less than $0.5 \mathrm{~kW}$ was marked in the afternoon otherwise.

We consider next the monthly electric generation energy during a year depicted in Figure 4. The data for amorphous and tandem panels are shown in the left and the right hands, respectively. Since Japan is located on the north semisphere of the earth, then in the midyear (the summer) the height of the sun is greater than that in the beginning and the end of the year (the winter) from the broad point of view. It is a peculiar point that the electric generation energy is obviously low in July and also little bit in June. It is because June and July is a typical climate which is known as a rainy season in Japan.

It is quite interesting to point out that the generation energy of the amorphous panel is higher than that of the tandem panel in the midyear, and vice versa in the other season. At low temperature the hybrid panel provides more energy in winter because it has the advantage to absorb light in the larger spectral range. But in summer the amorphous panel provides more energy in turn. The tandem panel, having a black color, absorbs more light and the panel temperature becomes higher. The higher panel temperature is assumed to suppress the electric generation energy. Theoretically the tandem panel provides larger energy but not so enough in the higher temperature. It has been reported that the influence of temperature on photo voltaic module $I-V$ curve [9] [10]. The influence mainly appears in the reduction of the open-circuit voltage [10] [11] [12].

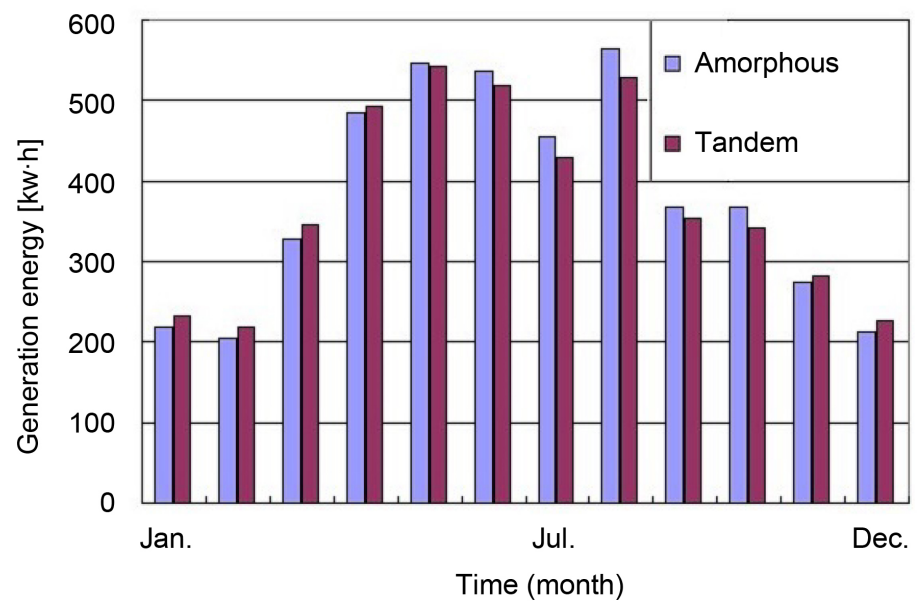

Figure 4. The monthly generation energy of the two types of solar cells: amorphous silicon (left) and tandem (right) solar cells. The dip in July is due to the rainy season in Japan. 
The tandem panel inherently rises in temperature because of its black color. The two solar cell panels are equipped with a well-known air cooling system [13] [14]. Nevertheless the panel temperature rises over 50 degree Celsius. In order to avoid the disadvantage of suppressing the generation energy, the planning of the more effective cooling system is then practically attractive to boost up the efficiency of the solar panel. One idea is the water circulating cooling system, in which the temperature-raised cooling water can be used for any other purpose at the same time. From the other point of view, the temperature difference between the solar panel and ambient air may be utilized to generate electricity additionally with the help of Peltier devices. In any case, the cost for the cooling system is critical in practical use.

\section{Conclusion}

The $3 \mathrm{~kW}$-class $>4.5 \mathrm{~kW}$-class solar panels were examined in a running test through a year, and the amorphous silicon type and tandem type were compared experimentally in a practical circumstance. The two kinds of solar panels were given by the same company. The amorphous silicon type gives a reddish brown color while the tandem type made of two layers (amorphous silicon and poly crystalline silicon layers) gives a black color. The obtained data shows roughly that the output power is directly related to the sun light intensity regardless of the temperature. The tandem type provides more energy in winter but contrarily the amorphous type provides more energy in summer. It is assumed that the tandem type tends to rise higher in temperature and degrades the efficiency of electric energy generation.

\section{Acknowledgements}

Authors would like to thank to Kaneka Co. Ltd. for their kind donation of the solar panel to Kobe City College of Technology.

\section{References}

[1] Markvart, T. (2000) Solar Electricity. 2nd Edition, John Wiley \& Sons Ltd., Chichester.

[2] Luque, A. and Hegedus, S. (2011) Handbook of Photovoltaic Science and Engineering. 2nd Edition, John Wiley \& Sons Ltd., West Sussex.

[3] Carlson, D.E. and Wronski, C.R. (1976) Amorphous Silicon Solar Cell. Applied Physics Letters, 28, 671. https://doi.org/10.1063/1.88617

[4] Yamaguchi, M. (2001) Present Status and Prospects of Photovoltaic Technologies in Japan. Renewable and Sustainable Energy Reviews, 5, 113-135.

[5] Repins, I., Contreras, M.A., Egaas, B., DeHart, C., Scharf, J., Perkins, C.L., To, B. and Noufi, R. (2008) 19.9\%-Efficient ZnO/CdS/CuInGaSe ${ }_{2}$ Solar Cell with $81.2 \%$ Fill Factor. Progress in Photovoltaics, 16, 235-239. https://doi.org/10.1002/pip.822

[6] Kaiser, B., Calvet, W., Murugasen, E., Ziegler, J., Jaegermann, W., Pust, S.E., Finger, F., Hoch, S., Blug, M. and Busse, J. (2015) Light Induced Hydrogen Generation with Silicon-Based Thin Film Tandem Solar Cells Used as Photocathode. International Journal of Hydrogen Energy, 40, 99-904. 
[7] Bhandari, K.P., Collier, J.M., Ellingson, R.J. and Apul, D.S. (2015) Energy Payback Time (EPBT) and Energy Return on Energy Invested (EROI) of Solar Photovoltaic Systems: A Systematic Review and Meta-Analysis. Renewable and Sustainable Energy Reviews, 47, 133-141.

[8] Nishimura, A., Hayashi, Y., Tanaka, K., Hirota, M., Kato, S., Ito, M., Araki, K. and $\mathrm{Hu}$, E.J. (2010) Life Cycle Assessment and Evaluation of Energy Payback Time on High-Concentration Photovoltaic Power Generation System. Applied Energy, 87, 2797-2807.

[9] Michael, S. (2009) On the Evaluation of Spectral Effects on Photovoltaic Modules Performance Parameters and Hotspots in Solar Cells. PhD Thesis, University of Fort Hare, Eastern Cape.

[10] Radziemska, E. (2003) The Effect of Temperature on the Power Drop in Crystalline Silicon Solar Cells. Renewable Energy, 28, 1-12.

[11] King, D.L. and Eckert, P.E. (1996) Characterizing (Rating) the Performance of Large Photovoltaic Arrays for All Operating Conditions. Proceeding of the 25th IEEE PV Specialists Conference, Washington DC, 13-17 May 1996, 1385-1388. https://doi.org/10.1109/pvsc.1996.564391

[12] Moshfegh, B. and Sandberg, M. (1998) Flow and Heat Transfer in the Air Gap behind Photovoltaic Panels. Renewable Sustainable Energy Reviews, 2, 287-301.

[13] Zhang, Z., Zhao, X., Smith, S., Xu, J. and Yu, X. (2012) Review of R\&D Progress and Practical Application of the Solar Photovoltaic/Thermal (PV/T) Technologies. Renewable and Sustainable Energy Reviews, 16, 599-617.

[14] Tonui, J.K. and Tripanagnostopoulos, Y. (2008) Performance Improvement of PV/T Solar Collectors with Natural Air Flow Operation. Solar Energy, 82, 1-12.

Submit or recommend next manuscript to SCIRP and we will provide best service for you:

Accepting pre-submission inquiries through Email, Facebook, LinkedIn, Twitter, etc. A wide selection of journals (inclusive of 9 subjects, more than 200 journals)

Providing 24-hour high-quality service

User-friendly online submission system

Fair and swift peer-review system

Efficient typesetting and proofreading procedure

Display of the result of downloads and visits, as well as the number of cited articles

Maximum dissemination of your research work

Submit your manuscript at: http://papersubmission.scirp.org/

Or contact jpee@scirp.org 